\title{
Respon Petani Terhadap Inovasi Penanaman Padi Sistem Gogo Rancah Lahan Sawah di Kecamatan Metro Timur Kota Metro
}

\section{Farmer Response to the Innovation of Rice Planting on the Gogo Sistem for Rice Fields in Metro Timur District, Metro City}

\author{
Oleh: \\ Arsendi Rifki Adipaty ${ }^{1 *}$, Helvi Yanfika², Indah Listiana ${ }^{2}$ \\ ${ }^{1}$ Jurusan Agribisnis, Fakultas Pertanian, Universitas Lampung \\ ${ }^{2}$ Program Studi Magister Penyuluuhan dan Komunikasi Pertanian, Fakultas Pertanian, Universitas Lampung \\ "E-mail: arsendi.adipaty@gmail.com
}

Received: Oktober 15, 2020; Revised: November 24, 2020; Accepted: December 18, 2020

\begin{abstract}
ABSTRAK
Inovasi penanaman padi sistem gogo rancah merupakan sistem penanaman padi yang dibudidayakan tidak berada dalam kondisi tergenang. Padi sistem gogo rancah di Kecamatan Metro Timur merupakan perpaduan antara sistem sawah dan sistem gogo rancah (ladang). Penelitian bertujuan untuk mengetahui respon petani terhadap penanaman padi sistem gogo rancah dan faktor-faktor yang berhubungan dengan respon petani terhadap penanaman sistem gogo rancah. Penelitian ini terdapat responden 54 orang petani di empat kelompok tani dan dilaksanakan pada Desember 2019. Metode penelitian yang digunakan ialah metode survei. Data dianalisis dengan pendekatan deskriptif dan uji korelasi Rank Spearman. Hasil penelitian menyatakan bahwa tingkat respon petani terhadap inovasi sistem gogo rancah tergolong dalam klasifikasi rendah. Faktor-faktor yang berhubungan dengan respon petani adalah umur petani, pendidikan formal dan sifat inovasi sistem gogo rancah. Faktor tidak berhubungan dengan respon petani adalah lama berusahatani, luas lahan, intensitas penyuluhan, dan pendapatan rumah tangga.
\end{abstract}

Kata kunci: respon, petani, inovasi, gogo rancah

\section{ABSTRACT}

The innovation of rice cultivation with the rice fields gogo rancah system is a system for cultivating rice that is not cultivated in stagnant water. The rice fields gogo rancah system were implemented by the East Metro Subdistrict is a combination of the paddy field system and the upland (field) system. This study aims to determine farmers response to rice cultivation in the rice fields gogo rancah system, to analyze the factors that related to the farmers response of the rice fields gogo rancah system. This study contained 54 farmers as respondents in four farmer groups and conducted in December 2019. The research method used was a survey method. Analize of data used descriptive and Rank Spearman Correlation Test. This study resulted in a low level of farmer response towards the innovation of the rice fields gogo rancah system. Factors related to farmer responses were farmer age, formal education and the nature of innovation in the rice fields gogo rancah system, while those that were not related to farmer responses were length of farming, land area, intensity of extension, and household income.

Keywords: response, farmers, innovation, upland scaffolding

\section{PENDAHULUAN}

Tanaman padi adalah tanaman pangan yang sering ditemui di Indonesia karena hasil olahan padi yaitu nasi menjadi makanan pokok masyarakat Indonesia.
Penduduk Indonesia yang menkonsumsi olahan padi mencapai 95 persen. Dengan besarnya masyarakat yang menkonsumsi olahan padi maka Negara Indonesia wajib 
dapat memenuhi ketersediaan bahan pangan tersebut (Sunarto dan Rauf, 2018). Ketersediaan pangan yang tidak dapat dipenuhi akan menciptakan ketidakstabilan ekonomi di dalam masyarakat. Ketersediaan pangan yang terganggu seperti melonjaknya harga beras pada krisis ekonomi pada tahun 1997 / 1998, sehingga menyebar dan membentuk masalah multidimensi sehingga menyebabkan gangguan sosial yang berbahaya bagi. keadaan ekonomi serta keadaan nasional. Negara wajib memastikan ketersediaan pangan untuk kelangsungan bangsa tersebut melakukan inovasi agar swasembada pangan tercapai (Alviana dkk, 2018).

Pulau Sumatera memiliki salah satu provinsi yaitu Provinsi Lampung yang menjadi produsen padi yang melebihi ratarata provinsi lain yang berada di pulau tersebut yaitu sebesar 5,149 ton per hektar (BPS, 2017). Kota Metro merupakan salah satu kabupaten/kota yang berada di Provinsi Lampung yang memproduksi tanaman pangan padi dengan urutan keempat dengan produktivitas sebesar 5,4 ton per hektar (Badan Pusat Statistik, 2019). Kecamatan Metro Timur ini memiliki produktivitas tertinggi dari kecamatan lainnya yaitu 5,872 ton per hektar, dengan luas panen yang terkecil (462 ha) (BPS, 2018).

Salah satu faktor yang mempengaruhi produktivitas penanaman padi adalah pemakaian inovasi di dalamnya. Inovasi dapat diartikan sebagai suatu hal baru seperti ide, produk, informasi teknologi, kelembagaan, prilaku, nilai-nilai dan praktek-praktek yang belum banyak diketahui masyarakat, dan belum bisa serta mau menerapkannya (Mardikanto, 2010). Salah satu inovasi padi sawah yang sedang dikembangkan oleh penyuluh yang berada di Kecamatan Metro Timur adalah sistem gogo rancah. Penanaman padi dengan sistem gogo rancah ini dimulai pada tahun 2018 sebelum memulai masa tanam atau dengan kata lain inovasi ini baru mau diterapkan penyuluh ke petani. Inovasi ini muncul untuk mengatasi keterlambatan masuknya air irigasi disetiap tahun genap.
Sistem gogo rancah merupakan sistem penanaman yang tanaman padinya tidak perlu ditumbuhkan dalam kondisi tergenang air. Penanaman padi sistem gogo rancah yang diterapkan oleh penyuluh Kecamatan Metro Timur merupakan perpaduan antara dari sistem sawah dan sistem gogo rancah (ladang). Pada penanaman padi sistem gogo rancah, petani disarankan untuk memulai tanam pada awal musim penghujan yang ditanam di lahan sawah selepas itu tanaman akan digenangi dengan air hujan berbarengan bersama frekuensi hujan yang bertambah (Kiswanto dan F. Y. Adriyani, 2019).

Penanaman tanaman padi dengan sistem gogo rancah ini memiliki keuntungan yaitu dengan menggunakan penanaman sistem gogo rancah ini, petani dapat memangkas biaya produktivitas untuk penanaman padi. Dengan menggunakan inovasi ini petani melakukan penghematan penggunaan air irigasi yang pada inovasi ini pemakaian air irigasi dilakukan dengan terputus-putus.Kendala yang terdapat pada inovasi penanaman padi sawah sistem gogo rancah ini yaitu produktivitas yang lebih kecil daripada sistem penanaman yang konvensional (Kiswanto dan F. Y. Adriyani, 2019). Berdasarkan hasil demplot di Kecamatan Metro Timur pada tahun 2018 yang ditanam oleh petani dan didampingi penyuluh menunjukkan bahwa tanaman padi yang memakai sistem konvensional pada lahan sawah menghasilkan gabah sebesar $1.600 \mathrm{~kg} / 2.500 \mathrm{~m}^{2}$ sedangkan tanaman padi yang memakai inovasi sistem gogo rancah ini memiliki hasil gabah sebesar $1.520 \mathrm{~kg} / 2.5000 \mathrm{~m}^{2}$.

Keuntungan dan kendala penerapan inovasi penanaman padi sawah sistem gogo rancah ini diduga bisa mempengaruhi respon petani terhadap inovasi tersebut. Respons petani terhadap suatu inovasi adalah salah satu faktor inti untuk memastikan perilaku petani sehingga menentukan apakah inovasi ini akab berlanjut atau tidak (Wijayanti dkk, 2015). Dengan memahami perilaku dari seseorang kemudian kita bisa menyimpulkan bagaimana respon dan perilaku yang dihasilkan dari individu tersebut tentang suatu keadaan maupun masalah yang akan dihadapi individu 
tersebut Walgito 2003). Penelitian ini bertujuan untuk mengetahui respon petani terhadap penanaman padi sistem gogo rancah serta untuk mengetahui faktor-faktor yang berhubungan dengan respon petani terhadap penanaman sistem gogo rancah.

\section{METODE PENELITIAN}

Penelitian ini dilaksanakan di Kecamatan Metro Timur Kota Metro dengan pertimbangan bahwa sistem gogo rancah merupakan program baru yang telah diterapkan di Kecamatan Metro Timur. Pelaksanaan penelitian ini dimulai pada Desember 2019 sampai dengan Januari 2020. Populasi penelitian adalah anggota kelompok tani di Kecamatan Metro Timur yang memiliki garapan lahan sawah sebanyak 114 orang. Penentuan sampel yang akan digunakan pada penelitian inovasi penanaman padi sistem gogo rancah memaiaki rumus Slovin dengan rumus sebagai berikut (Noor, 2012).

$$
\begin{aligned}
& \text { e } \quad \text { Error level (ditentukan 10\% } \\
& \text { beserta tingkat kepercayaan 90\%) } \\
& \mathrm{n} \quad=\text { Total sampel } \\
& \mathrm{N}=\text { Total populasi petani padi sawah }
\end{aligned}
$$

Hasil dari perhitungan memakai rumus diatas memperoleh sampel sebanyak 54 responden petani padi sawah. Data dikumpulkan menggunakan beberapa teknik, antara lain teknik pengumpulan data kuesioner beserta teknik pengumpulan data dokumentasi. Untuk menjawab tujuan penelitian digunakan metode deskriptif sehinga tujuan pertama dapat terjawab dan metode analisis Rank Spearman sehingga tujuan kedua dapat terjawab. Faktor yang diduga berhubungan dengan penelitian ini ialah umur petani (X1), pendidikan formal petani (X2), lama berusahatani (X3), luas lahan petani (X4), intensitas penyuluhan (X5), pendapatan rumah tangga (X6), dan sifat inovasi sistem gogo rancah (X7).

\section{HASIL DAN PEMBAHASAN}

\section{Pemaparan Variabel X (Faktor Respon)}

Petani berada pada kelompok usia produktif (15 - 64 tahun) memiliki jumlah responden tertinggi yaitu sebanyak 52 petani $(96,3 \%)$. Seseorang yang berada pada usia produktif cenderung mempunyai kapasitas tubuh yang optimal beserta mempunyai respon yang bagus untuk mendapatkan sesuatu yang belum pernah diketahui untuk meningkatkan usahatani petani tersebut. Usia tidak produktif cenderung memiliki kesulitan dalam menerima sesuatu hal yang belum pernah diketahui untuk usahatani yang dimilikinya. Hal ini disebabkan oleh pemikiran para petani yang berbeda-beda dalam menjalankan usahataninya

\begin{tabular}{|c|c|c|c|}
\hline No & Variabel X & Klasifikasi & $\begin{array}{c}\text { Jumlah } \\
\text { Responden }\end{array}$ \\
\hline \multirow[t]{3}{*}{1} & Usia Petani & Belum Produktif $(<15)$ & 0 \\
\hline & & Produktif $(15-64)$ & 52 \\
\hline & & Tidak Produktif (> 64) & 2 \\
\hline \multirow[t]{4}{*}{2} & Tingkat & Pendidikan rendah $(\leq 9)$ & 48 \\
\hline & Pendidikan & Pendidikan menengah & 6 \\
\hline & Formal & $(10-12)$ & \\
\hline & & Pendidikan tinggi $(>12)$ & 0 \\
\hline \multirow[t]{3}{*}{3} & Lama & Rendah $(8,00-15,33)$ & 25 \\
\hline & Berusahatani & Sedang $(15,34-22,66)$ & 17 \\
\hline & & Tinggi $(22,67-30,00)$ & 12 \\
\hline \multirow[t]{3}{*}{4} & Luas Lahan & Sempit $(0,125-0,5833)$ & 50 \\
\hline & & Sedang $(0,5834-1,041)$ & 3 \\
\hline & & Luas $(1,042-1,50)$ & 1 \\
\hline \multirow[t]{3}{*}{5} & Intensitas & Rendah $(0-3)$ & 11 \\
\hline & Penyuluhan & Sedang $(4-5)$ & 27 \\
\hline & & Tinggi $(>6)$ & 16 \\
\hline \multirow[t]{4}{*}{6} & Pendapatan & Rendah (Rp. 1.100.000 - & 16 \\
\hline & Rumah & Rp. 1.666.667) & \\
\hline & Tangga & $\begin{array}{l}\text { Sedang (Rp. 1.666.668 - } \\
\text { Rp. 2.233.335) }\end{array}$ & 28 \\
\hline & & $\begin{array}{l}\text { Tinggi (Rp. 2.233.336 - } \\
\text { Rp. 2.800.000) }\end{array}$ & 10 \\
\hline \multirow[t]{3}{*}{7} & Sifat Inovasi & Rendah $(35,0-51,7)$ & 30 \\
\hline & Gogo & Sedang $(51,8-68,5)$ & 9 \\
\hline & Rancah & Tinggi $(68,6-85,0)$ & 15 \\
\hline
\end{tabular}
(Kusumawati, 2015).

\section{Tabel 1.}

Sebaran responden berdasarkan Variabel X

Tingkat pendidikan rendah termasuk yang paling tinggi yaitu sebanyak 48 petani $(88,9 \%)$. Berdasarkan hasil penelitian lapangan, rendahnya tingkat pendidikan disebabkan mahalnya biaya pendidikan 
formal bagi keluarga petani yang menyebabkan banyak keluarga petani putus sekolah. Muksin (2007) mengatakan, pendidikan formal adalah suatu prosedur pembelajaran yang harus dapat menghasilkan modal bagi keterampilan dan kapasitas berpikir (soft and hard skills). Dari penjelasan tersebut dapat disimpulkan tingkat pendidikan yang rendah akan berdampak pada rendahnya respon yang dimiliki seseorang dalam menerima hal baru begitu pun sebaliknya.

Klasifikasi lama berusahatani yang paling tinggi yaitu klasifikasi rendah dengan jumlah 25 petani (46,3\%). Menurut Balinda (2012) petani yang lama dalam bekerja di usahatani tersebut maka semakin banyak ilmu yang diperolehnya. Petani yang terdapat didalam klasifikasi rendah bisa memperoleh ilmu berusahatani yang berasal dari demplot percobaan yang dikelola oleh penyuluh agar petani dapat lebih mengetahui tentang inovasi sistem tanam gogo rancah.

Responden sebanyak 50 petani $(92,6 \%)$ termasuk kedalam kategori lahan sempit. Menurut Putra (2009) sempitnya lahan merupakan dampak dari sistem pewarisan dan perubahan tata guna lahan yang menyebabkan skala usaha petani terus menyusut. Untuk meningkatkan produkstivitas padi diperlukan sebuah inovasi supaya petani yang memiliki luas lahan kecil dapat meningkatkan pendapatannya.

Responden sebanyak 27 petani (50,00\%) memiliki intensitas penyuluhan klasifikasi sedang. Dari data diatas bisa dilihat bahwa kebanyakan petani masih jarang hadir dalam penyuluhan yang dilakukan oleh penyuluh. Banyaknya petani yang tidak terdapat dalam klasifikasi tinggi berdampak pada kurangnya pengetahuan terhadap penanaman padi sistem gogoh rancah yang akan dilakukan.

Responden sebanyak 28 petani $(51,85 \%)$ masuk dalam klasifikasi pendapatan sedang. Pendapatan petani yang tergolong sedang dikarenakan produksi padi yang diterima petani mengalami penurunan. Petani enggan melakukan Sistem Gogo Rancah dikarena jarak tanam yang digunakan dalam Sistem Gogo Rancah lebih luas dengan jarak tanam yang digunakan dalam sistem penanaman seperti biasanya, sehingga mengakibatkan menurunknya jumlah produksi padi yang petani dapat.

Sifat inovasi gogo rancah masuk dalam klasifikasi rendah, yaitu sebanyak 30 petani $(55,56 \%)$. Hal ini menunjukkan bahwa inovasi yang diterima petani dalam sistem gogoh rancah tergolong rendah. Rendahnya tingkat inovasi yang diterima petani disebabkan masih ada sifat-sifat inovasi yang kurang diminati oleh petani. Jumlah pupuk yang disarankan oleh penyuluh lebih banyak daripada yang biasa digunakan petani, hal ini dikarenakan dalam sistem gogo rancah pada penyiapan lahan diperlukan tambahan pupuk (pupuk kandang, kompos). Kelangkaan pupuk juga menjadi hambatan petani untuk memberikan dosis pupuk yang sesuai untuk tanaman padinya.

\section{Pemaparan Variabel Y (Respon Petani)}

Sebanyak 34 petani $(62,96 \%)$ memiliki respon yang rendah terhadap Sistem Gogo Rancah. Berdasarkan hasil penelitian dalam penyiapan lahan petani diharuskan melakukan pengolahan lahan menggunakan cara olah tanah minimum dan pengolahan dilakukan satu minggu sebelum tanam, namun petani tidak melakukan itu karena mereka beranggapan pengolahan lahan tersebut membutuhkan waktu yang lama sehingga petani lebih memilih cara pengolahan lahan yang biasa mereka gunakan.

Dalam penanaman sistem gogo rancah, petani disarankan menggunakan mesin corn planer sehingga jarak tanam yang digunakan sesusai dengan anjuran yaitu $30 \times 30 \mathrm{~cm}$, namun petani menanam padi dengan jarak tanam yang tidak sesuai anjuran, petani beranggapan jarak tanam $30 \times 30 \mathrm{~cm}$ terlalu jauh. Hal tersebut disebabkan petani kurang tertarik oleh manfaat yang disediakan Sistem Gogo Rancah. Petani beranggapan sistem 
tanam tidak terlalu berpengaruh dalam produksi. Petani juga didorong untuk menggunakan benih unggul dan bersertifikat, namun kenyataannya masih ada sebagian petani yang memakai benih hasil dari usahataninya. Petani berpikir kualitas benih antara benih unggul bersertifikat dan benih yang didapat dari hasil panen memiliki kualitas yang tidak jauh berbeda. Petani di daerah penelitian telah mengetahui jumlah pupuk yang sesuai dengan anjuran penyuluh yaitu Sp36 $100 \mathrm{~kg}, \mathrm{KCl} 200 \mathrm{~kg}$, Urea $300 \mathrm{~kg}$ dan pupuk organik $2000 \mathrm{~kg}$, namun tidak sedikit pula yang setuju menggunakan dalam usahatani padi dan hanya memberikan dosis pupuk seadanya saja. Petani lebih mengikuti pengalaman berusahatani dibandingkan mengikuti saran dari penyuluh.

Dalam pengendalian gulma dan penyakit, petani disarankan untuk menggunakan herbisida sistemik dan herbisida kontak, namun banyak petani yang tidak mengunakan herbisida yang telah dianjurkan. Menurut petani OPT seperti wereng dan penyakit tanaman patah leher tidak dapat diatasi dengan menggunakan inovasi sistem gogo rancah sehingga hal tersebut membuat produksi padi belum optimal. Panen dalam Sistem Gogo Rancah petani dianjurkan menggunakan threser bermesin kecil, namun berdasarkan hasil lapangan masih banyak petani yang melakukan panen menggunakan sistem manual.

\section{Hubungan Variabel X dan Y}

Hubungan antara variabel X (faktorfaktor yang berhubungan dengan respon petani terhadap Sistem Gogo Rancah) dengan variabel Y (Respon petani terhadap Sistem Gogo Rancah) dikaji dengan memakai statistika nonparametrik yaitu uji korelasi Rank Spearman. Faktor umur petani (X1), pendidikan formal petani (X2), dan Sifat inovasi sistem gogo rancah (X7) berhubungan dengan Respon petani terhadap Sistem Gogo Rancah di
Kecamatan Metro Timur Kota Metro, sedangkan lama berusahatani (X3), luas lahan (X4), intensitas penyuluhan (X5), dan pendapatan rumah tangga (X6), tidak berhubungan secara nyata.

\section{Tabel 2.}

Hasil pengkajian faktor-faktor yang diduga berhubungan dengan Respon petani terhadap Sistem Gogo Rancah

\begin{tabular}{|c|c|c|c|c|}
\hline No & Variabel X & $\begin{array}{c}\text { Variabel } \\
\text { Y }\end{array}$ & $\begin{array}{c}\text { Koefisien } \\
\text { korelasi } \\
\text { (rs) }\end{array}$ & $\begin{array}{c}\text { sig. } \\
(2- \\
\text { tailed) }\end{array}$ \\
\hline 1 & Umur Petani & & $-0,321 *$ & 0,018 \\
\hline 2 & $\begin{array}{l}\text { Pendidikan } \\
\text { Formal Petani }\end{array}$ & & $0,703 *$ & 0,000 \\
\hline 3 & $\begin{array}{l}\text { Lama } \\
\text { Berusahatani }\end{array}$ & $\begin{array}{l}\text { Respon } \\
\text { petani } \\
\text { terhadap }\end{array}$ & $-0,236^{\mathrm{tn}}$ & 0,085 \\
\hline 4 & $\begin{array}{l}\text { Luas Lahan } \\
\text { Sawah }\end{array}$ & $\begin{array}{l}\text { Sistem } \\
\text { Gogo }\end{array}$ & $-0,035^{\mathrm{tn}}$ & 0,803 \\
\hline 5 & $\begin{array}{l}\text { Intensitas } \\
\text { Penyuluhan }\end{array}$ & Rancah & $-0,083^{\text {th }}$ & 0,551 \\
\hline 6 & $\begin{array}{l}\text { Pendapatan } \\
\text { Rumah Tangga }\end{array}$ & & $-0,219^{\mathrm{tn}}$ & 0,112 \\
\hline 7 & $\begin{array}{l}\text { Sifat Inovasi } \\
\text { Sistem Gogo } \\
\text { Rancah }\end{array}$ & & $0,889 * *$ & 0,000 \\
\hline
\end{tabular}

Hubungan antara umur petani dengan dengan respon petani terhadap Sistem Gogo Rancah

Hasil pengkajian korelasi Rank Spearman memperlihatkan bahwasanya umur petani berpengaruh terbalik, artinya semakin tinggi umur petani maka respon petani juga semakin rendah.. Hal tersebut dihasilkan dari data nilai koefisien korelasi Spearman Rank (rs) senilai $-0,321 *$, dan besar signifikansi 0,018 tidak melewati nilai dari $\alpha(0,05)$, sehingga dapat ditarik jawaban hipotesis ialah menerima $\mathrm{H} 1$ kemudian menolak $\mathrm{H} 0$, yaitu terdapat hubungan nyata antara umur petani dengan dengan respon petani terhadap Sistem Gogo Rancah di Kecamatan Metro Timur Kota Metro. Jawaban tentang hipotesis tersebut berlawanan dengan penelitian Kusumawati dkk (2015) tentang preferensi petani terhadap Sistem Tanam Jajar Legowo di Desa Tambakrejo Kecamatan Patebon Kabupaten Kendal. 
Hubungan antara tingkat pendidikan formal petani dengan dengan respon petani terhadap Sistem Gogo Rancah

Hasil pengkajian korelasi Rank Spearman memperlihatkan bahwasanya koefisien korelasi Rank Spearman (rs) adalah $0,703 *$, dan besar signifikansi 0,000 tidak melewati nilai dari $\alpha(0,05)$, sehingga dapat ditarik jawaban hipotesis ialah menerima $\mathrm{H} 1$ kemudian menolak $\mathrm{H} 0$, yaitu terdapat hubungan nyata antara tingkat pendidikan formal petani dengan dengan respon petani terhadap Sistem Gogo Rancah di Kecamatan Metro Timur Kota Metro. Jawaban tentang hipotesis tersebut tidak berlawanan dengan penelitian Budianto dkk (2016). Penelitian tersebut mengenai reapon anggota kelompok tani terhadap Program Pengembangan Usaha Agribisnis Pedesaan (PUAP) di kecamatan Kebun Tebu Kabupaten Lampung Barat.

Hubungan antara lama berusahatani dengan dengan respon petani terhadap Sistem Gogo Rancah

Hasil pengkajian korelasi Rank Spearman memperlihatkan bahwasanya lama berusahatani berpengaruh terbalik, artinya semakin lama berusahatani maka respon petani juga semakin rendah.. Hal tersebut dihasilkan dari data nilai koefisien korelasi Spearman Rank (rs) senilai -0,236 dan besar signifikansi 0,085 melewati nilai dari $\alpha(0,05)$, sehingga dapat ditarik jawaban hipotesis ialah menerima $\mathrm{H} 0$ kemudian menolak $\mathrm{H} 1$, yaitu tidak ada hubungan nyata antara lama berusahatani dengan dengan respon petani terhadap Sistem Gogo Rancah di Kecamatan Metro Timur Kota Metro. Jawaban tentang hipotesis tersebut tidak berlawanan dengan penelitian Balinda (2012) mengenai respon petani apel terhadap industrialisasi pertanian di Desa Poncokusumo, Kecamatan Poncokusumo Kabupaten Malang.
Hubungan antara luas lahan dengan dengan respon petani terhadap Sistem Gogo Rancah

Hasil pengkajian korelasi Rank Spearman memperlihatkan bahwasanya luas lahan berpengaruh terbalik, artinya semakin luas lahan petani maka maka respon petani juga semakin rendah. Hal tersebut dihasilkan dari data nilai koefisien korelasi Rank Spearman (rs) senilai -0,035, dan besar signifikansi 0,803 melewati nilai dari $\alpha(0,05)$, sehingga dapat ditarik jawaban hipotesis ialah menerima $\mathrm{H} 0$, kemudian menolak $\mathrm{H} 1$, yaitu tidak ada hubungan nyata antara luas lahan dengan dengan respon petani terhadap Sistem Gogo Rancah di Kecamatan Metro Timur Kota Metro. Jawaban tentang hipotesis tersebut berlawanan dengan penelitian Balinda (2012).

Hubungan antara intensitas penyuluhan dengan respon petani terhadap Sistem Gogo Rancah

Hasil pengkajian korelasi Rank Spearman memperlihatkan bahwasanya koefisien korelasi Rank Spearman (rs) adalah $-0,083$, dan besar signifikansi 0,551 melewati nilai dari $\alpha(0,05)$, sehingga dapat ditarik jawaban hipotesis ialah menerima $\mathrm{H} 0$ kemudian menolak $\mathrm{H} 1$, yaitu tidak ada hubungan nyata antara intensitas penyuluhan dengan dengan respon petani terhadap Sistem Gogo Rancah di Kecamatan Metro Timur Kota Metro. Jawaban tentang hipotesis tersebut dikarenakan masih banyak petani yang jarang hadir dalam penyuluhan yang dilakukan oleh penyuluh. Banyaknya petani yang jarang hadir dalam penyuluhan berdampak pada kurangnya pengetahuan petani terhadap penanaman padi sistem gogoh rancah yang sedang dilakukan.

Hubungan antara pendapatan rumah tangga dengan respon petani terhadap Sistem Gogo Rancah

Hasil pengkajian korelasi Rank Spearman memperlihatkan bahwasanya pendapatan rumah tangga berpengaruh terbalik, artinya semakin besar pendapatan rumah tangga petani maka maka respon petani 
juga semakin rendah. Hal tersebut dihasilkan dari data nilai koefisien korelasi Rank Spearman (rs) senilai -0,219, dan besar signifikansi 0,112 melewati nilai dari $\alpha(0,05)$, sehingga dapat ditarik jawaban hipotesis ialah menerima $\mathrm{H} 0$, kemudian menolak H1, yaitu tidak ada hubungan nyata antara pendapatan rumah tangga dengan dengan respon petani terhadap Sistem Gogo Rancah di Kecamatan Metro Timur Kota Metro. Bedasarkan hasil lapangan menunjukkan bahwa pendapatan yang di terima masih tergolong sedang. Pendapatan petani yang tergolong sedang dikarenakan produksi padi yang diterima petani mengalami penurunan. Petani enggan melakukan Sistem Gogo Rancah dikarena jarak tanam yang digunakan dalam Sistem Gogo Rancah lebih luas dengan jarak tanam yang digunakan dalam sistem penanaman seperti biasanya, dengan jarak tanam yang lebih luas akan menurunkan jumlah produksi padi.

Hubungan antara sifat inovasi sistem gogo rancah dengan respon petani terhadap Sistem Gogo Rancah

Hasil pengkajian korelasi Rank Spearman memperlihatkan bahwasanya koefisien korelasi rank spearman (rs) senilai $0.889 * *$, dan besar signifikansi 0,000 tidak melewati nilai dari $\alpha(0,05)$, sehingga dapat ditarik jawaban hipotesis ialah menerima $\mathrm{H} 1$ kemudian menolak $\mathrm{H} 0$, yaitu terdapat hubungan nyata antara sifat inovasi sistem gogo rancah dengan dengan respon petani terhadap Sistem Gogo Rancah di Kecamatan Metro Timur Kota Metro. Jawaban tentang hipotesis tersebut tidak berlawanan dengan penelitian Laila (2012) tentang penerapan petani padi sawah terhadap Sistem Tanam Jajar Legowo Kecamatan Polongbangkeng Utara Kabupaten Takalar.

\section{SIMPULAN}

Respon petani terhadap inovasi sistem gogo rancah di Kecamatan Metro Timur Kota metro masih tergolong rendah.
Respon petani yang rendah dikarenakan petani merasa inovasi penanaman padi sistem gogo rancah lahan sawah tidak sesuai dengan pengetahuan yang mereka miliki. Sebagian besar petani jarang hadir dalam penyuluhan sehingga mereka tidak mengetahui informasi yang mendetail tentang inovasi penanaman padi sistem gogo rancah lahan sawah. Petani juga masih merasa nyaman dengan usahatani yang sudah dijalankan oleh petani sampai sekarang.

Faktor-faktor yang berhubungan dengan respon petani terhadap Sistem Gogo Rancah di Kecamatan Metro Timur Kota metro adalah umur petani, tingkat pendidikan formal petani, dan sifat inovasi sistem gogo rancah, sedangkan yang tidak memiliki hubungan adalah luas lahan sawah, intensitas penyuluhan, lama berusahatani, pendapatan rumah tangga, dan status kepemilikan lahan.

\section{DAFTAR PUSTAKA}

Alviana E. D., D. T. Gultom., Y A. Syarif. 2018. Respon Petani Terhadap Sistem Tanam Jajar Legowo Di Kecamatan Tumijajar Kabupaten Tulang Bawang Barat. Skripsi. Universitas Lampung. Lampung

Badan Pusat Statistik. 2017. Produksi Tanaman Pangan Tahun 2015. BPS Nasional. Indonesia . 2018. Kota Metro dalam Angka. BPS Kota Metro. Metro. 2019. Produktivitas Padi Sawah Provinsi Lampung Tahun 2018. BPS Provinsi Lampung. Bandar Lampung.

Balinda, Nur. 2012. Respon Petani Apel terhadap Industrialisasi Pertanian (Kasus di Desa Poncokusumo, Kecamatan Poncokusumo, Kabupaten Malang).SEPA. Vol. 8 No. 2 Pebruari $2012: 51-182$.

Budianto, H., Sumaryo G, S., dan Begem V. 2016. Respon Anggota Kelompok Tani terhadap Program Pengembangan Usaha Agribisnis Perdesaan (PUAP) di Kecamatan Kebun Tebu Kabupaten 
Lampung Barat. JIIA, Volume 4, No. 2, Mei 2016.

Kiswanto dan F. Y. Adriyani. 2019. Budidaya Padi Sistem Gogo Rancah di Lahan Sawah untuk Mengantisipasi Kekurangan Air. http://cybex.pertanian.go.id/mobile/artike 1/80679/Budidaya-Padi-Sistem-Gogo-

Rancah--di-Lahan-Sawah--untukMengantisipasi-Kekurangan-Air/. diakses pada tanggal 20 Februari 2021.

Kusumawati, Nani., Lutfi Aris Sasongko dan Rossi Prabowo. Preferensi Petani terhadap Sistem Tanam Padi Jajar Legowo. Mediagro. Vol. 11. No. 1.2015. Hal 75- 91.

Laila, Hajrah., Saleh, Ali S., dan Saadah. 2012. Adopsi Petani Padi Sawah terhadap Sistem Tanam Jajar Legowo 2:1 di Kecamatan Polong bangkeng Utara, Kabupaten Takalar. J. Sains \& Teknologi. Vol.12No.3: 255 264ISSN 1411-4674.

Muksin. 2007. Kompetensi Pemuda Tani yang Perlu Dikembangkan di Jawa Timur. Disertasi. Institut Pertanian
Bogor. Bogor.

Noor, J. 2012. Metodologi Penelitian Skripsi, Tesis, Disertasi dan Karya Ilmiah. Prenada Media Group. Jakarta Purnowo dan P. Heni. 2007. Budidaya 8 Jenis Tanaman Pangan Unggul. Penebar Swadaya. Bogor.

Putra, Cory Wastu. 2009. Dampak Fragmentasi Lahan terhdapa Biaya Produksi dan Biaya Transaksi Petani Pemilik. Bogor. IPB Scientic Repository.

Sunanto dan A. W. Rauf. 2018. Respon Petani Terhadap Pelaksanaan Displai Padi Gogo VUB Pada Lahan Sub Optimal Di Sulawesi Selatan. JSEP. Volume 14, No. 2, Juni 2018, Halaman 143-160 .

Walgito, B. 2003.Psikologi Sosial Suatu Pengantar. Andi. Yogyakarta.

Wijayanti, A, Subejo, Harsoyo. 2015. Respons Petani Terhadap Inovasi Budidaya Dan Pemanfaatan Sorgum Di Kecamatan Srandakan Kabupaten Bantul. Agro Ekonomi. Vol. 26/No. 2 